\title{
Comparative quantification of umbilical cord blood CD34+ and CD34+ bright cells using the ProCount ${ }^{\mathrm{m}}-\mathrm{BD}$ and ISHAGE protocols
}

P. Pranke ${ }^{1,3,4}$

J. Hendrikx ${ }^{4}$,

G. Alespeiti ${ }^{4}$,

N. Nardi2,

P. Rubinstein ${ }^{5}$ and J. Visser ${ }^{4}$
${ }^{1}$ Laboratório de Hematologia, Faculdade de Farmácia,

${ }^{2}$ Departamento de Genética, Universidade Federal do Rio Grande do Sul, Porto Alegre, RS, Brasil

${ }^{3}$ Departamento de Análises Clínicas, Faculdade de Farmácia,

Pontifícia Universidade Católica do Rio Grande do Sul, Porto Alegre, RS, Brasil

${ }^{4}$ Stem Cell Biology, ${ }^{5}$ Immunogenetics, New York Blood Center, New York, NY, USA

\section{Correspondence}

\section{P. Pranke}

Laboratório de Hematologia

Faculdade de Farmácia, UFRGS

Av. Ipiranga, 2752

90160-000 Porto Alegre, RS

Brasil

Fax: + 55-51-3316-5437

E-mail: ppranke@adufrgs.ufrgs.br

Research supported by New York Blood Center, New York, USA, and CAPES

Received August 31, 2005

Accepted April 5, 2006

\section{Abstract}

The total number of CD34+ cells is the most relevant clinical parameter when selecting human umbilical cord blood (HUCB) for transplantation. The objective of the present study was to compare the two most commonly used CD34+ cell quantification methods (ISHAGE protocol and ProCount ${ }^{\mathrm{TM}}$ - BD) and analyze the CD34+ bright cells whose 7-amino actinomycin D (7AAD) analysis suggests are apoptotic or dead cells. Twenty-six HUCB samples obtained at the Placental Blood Program of New York Blood Center were evaluated. The absolute numbers of CD34+ cells evaluated by the ISHAGE (with exclusion of 7AAD+ cells) and ProCount ${ }^{\mathrm{TM}}$ (with exclusion of CD34+ bright cells) were determined. Using the ISHAGE protocol we found $35.6 \pm 19.4 \mathrm{CD} 34+$ cells $/ \mu \mathrm{L}$ and with the ProCount ${ }^{\mathrm{TM}}$ method we found $36.6 \pm 23.2 \mathrm{CD} 34+$ cells $/ \mu \mathrm{L}$. With the ProCount ${ }^{\mathrm{TM}}$ method, CD34+ bright cell counts were $9.3 \pm 8.2$ cells $/ \mu \mathrm{L}$. CD34+ bright and regular cells were individually analyzed by the ISHAGE protocol. Only about $1.8 \%$ of the bright CD34+ cells are alive, whereas a small part $(19.0 \%)$ is undergoing apoptosis and most of them $(79.2 \%)$ are dead cells. Our study showed that the two methods produced similar results and that 7AAD is important to exclude CD34 bright cells. These results will be of value to assist in the correct counting of CD34+ cells and to choose the best HUCB unit for transplantation, i.e., the unit with the greatest number of potentially viable stem cells for the reconstitution of bone marrow. This increases the likelihood of success of the transplant and, therefore, the survival of the patient.

\section{Key words}

- Hematopoietic stem cell

- Human umbilical cord

blood

- CD34+

- ISHAGE

- ProCount

\section{Introduction}

The hematopoietic stem cell has great capacity for self-renewal and cellular proliferation. CD34 molecules, together with the presence of FLT3 and Thy 1 and the absence of HLA-DR, CD38 and specific line markers, are cellular labels used in the identification of primitive classes of stem cells (1-7).

The use of human umbilical cord blood 
(HUCB) as a source of hematopoietic stem cells in transplantation has increased greatly since $1997(8,9)$, mainly due to the advantages of this source in comparison with bone marrow: an unlimited supply since this material is discarded following birth, immediate availability of the blood, given that it is stored in cord banks, and a lower incidence of graft-versus-host disease (2,10-13).

The total number of CD34+ cells is the clinically most relevant parameter in the selection of cord blood units for transplantation. The two most widely employed methods of quantification of HUCB CD34+ cells are the International Society of Hematotherapy and Graft Engineering (ISHAGE) protocol (14) and the ProCount ${ }^{\mathrm{TM}}$ - BD method (Becton Dickinson).

An interesting fact in relation to the two approaches is that when the ProCount ${ }^{\mathrm{TM}}$ method is applied to HUCB, two populations of CD34+cells are observed, one highly fluorescent, and one with regular fluorescence intensity. The population of very bright CD34+ cells is not observed with the ISHAGE method. This fact is particularly important given that Lögdberg et al. (15) suggest that bright CD34+ cells are cells in apoptosis and, therefore, not suitable for use in transplantation. According to Lögdberg et al., the average frequency of these bright CD34+ cells in the units of umbilical cord blood was approximately 20\% (range between 0 and $75 \%$ ) of the total positive CD34+ cells in the umbilical cord blood. Recently, Greco et al. (16) also reported high frequencies of very bright CD34+ cells in HUCB using the ProCount method.

The dye 7-amino actinomycin D (7AAD) identifies dead cells and weakly label cells in apoptosis (17). Using 7AAD it is possible to visualize the bright CD34+ cells that appear with the ProCount ${ }^{\mathrm{TM}}$ method, but not with the ISHAGE protocol, and to identify whether these cells are dead or in apoptosis. In many transplant centers throughout the world, the total number of positive CD34+ cells is used as a parameter when selecting umbilical cord units suitable for transplantation.

However, no analysis is performed to identify whether these cells show regular fluorescence (i.e., they are suitable for transplantation) or are bright (probably not contributing to engraftment), which may lead to errors when selecting the umbilical cord blood unit. The number of CD34+ cells is a crucial factor regarding whether a graft "takes" or not and is, therefore, crucial for the success of the transplant. The failure to exclude bright CD34+ cells when the cord unit is selected may be one of the reasons for the failure of some transplants using human umbilical cord blood.

The aim of the present study was to perform stem cell counts in umbilical cord blood comparing the two most widely used methods in umbilical cord blood banks. Another objective was also to further analyze the CD34+ bright cells which have been suggested to be apoptotic and as such are not useful in transplantation procedures (15). Dead and apoptotic cells have been identified with 7AAD (17). The present study contributes to the identification of the bright CD34+ cells by the two methods used for the counting of stem cells in umbilical cord blood, comparing the ProCount ${ }^{\mathrm{TM}}$ method from Becton Dickinson and the ISHAGE protocol (14).

\section{Material and Methods}

Twenty-six umbilical cord blood samples obtained at the Placental Blood Program of New York Blood Center (New York, NY, USA) were evaluated.

The CD34+ cell count was carried out by means of comparative assessment using a) the ISHAGE protocol and the CellQuest program from Becton Dickinson (San Jose, CA, USA), and b) the ProCount ${ }^{\mathrm{TM}}$ protocol from Becton Dickinson.

In order to quantify the CD34+ cells from umbilical cord blood using the ISHAGE 
protocol, $100 \mu \mathrm{L}$ of fresh total umbilical cord blood was incubated with $10 \mu \mathrm{L}$ of antiCD45-FITC antibody and $10 \mu \mathrm{L}$ of antiCD34-PE antibody (Pharmingen/Becton Dickinson, San Jose, CA, USA) in duplicate. Other samples were incubated with anti-CD45-FITC/isotype as control. All samples in the ISHAGE protocol were incubated with 7AAD for the identification of dead cells or those in apoptosis. Absolute cell counts were possible by the addition of Flow-Count beads (Beckman Coulter, Fullerton, CA, USA) to the tubes. 7AAD was used at a concentration of $1 \mu \mathrm{g} / \mathrm{mL}$ in each tube with $100 \mu \mathrm{L}$ of fresh total umbilical cord blood and $100 \mu \mathrm{L}$ beads. For the CD34+ cell count using the ProCount ${ }^{\mathrm{TM}}$ protocol, 50 $\mu \mathrm{L}$ of fresh total umbilical cord blood was incubated with control antibodies and antiCD34 antibody from the ProCount ${ }^{\mathrm{TM}}$ kit from Becton Dickinson using $20 \mu \mathrm{L}$ of antihuman CD34/PE monoclonal antibodies and anti-human CD45/FITC.

The acquisition and analysis of the data were performed using a flow cytometer (FACSCalibur; Becton Dickinson) equipped with a 488-nm argon-ion laser, using CellQuest and ProCount ${ }^{\mathrm{TM}}$ software packages. The analyses were performed during the study of the expression of the marker molecules with the monoclonal antibodies.

CD34+ cells were enumerated and analyzed twice by both methods. The bright CD34+ cells were excluded in the first analysis and included in the second. This made it possible to perform a qualitative and quantitative assessment of the population of the bright CD34+ cells within the total population of CD34+cells, and to determine whether these cells were labeled with 7AAD.

The statistical analysis was carried out using the SPSS program, version 8.0, with the level of significance set at $\mathrm{P}<0.05$.

\section{Results}

Twenty-six cord blood samples were an- alyzed in this study. The cord blood volume ranged from 9.8 to $59.1 \mathrm{~mL}$, with an average of $40.7 \pm 14.8 \mathrm{~mL}$.

The CD34+ cell count by the ISHAGE protocol was done in duplicate. There were no significant differences, since the Wilcoxon test showed $\mathrm{P}=0.476$ in relation to the number of CD34+ cells $/ \mu \mathrm{L}$ and $\mathrm{P}=0.788$ in relation to the relative number of $\mathrm{CD} 34+$ cells among the CD45+ cells.

The absolute numbers of CD34+ cells and relative number among CD45+ cells evaluated by the ISHAGE (with exclusion of 7AAD+ cells) and ProCount ${ }^{\mathrm{TM}}$ (with exclusion of CD34+ bright cells) protocols were not statistically different according to the Wilcoxon test $(\mathrm{P}=0.747$ and 0.732 , respectively). The results are summarized in Table 1 and Figure 1.

According to the ProCount ${ }^{\mathrm{TM}}$ protocol, CD34+ bright cell counts were $9.3 \pm 8.2$ (1.0-34.5) cells/ $\mu \mathrm{L}$ or $0.077 \pm 0.081 \%(0.007$ $0.383 \%)$ among CD45+ cells. The simulta-

Table 1. Absolute number of CD34+ cells/ $\mu \mathrm{L}$ and relative number of $\mathrm{CD} 34+$ cells among CD45+ cells in umbilical cord blood evaluated with the ISHAGE and ProCount $^{\text {TM }}$ protocols.

\begin{tabular}{lcc}
\hline & CD34+ cells $/ \mu \mathrm{L}$ & \% CD34+ cells among CD45+ cells \\
\hline ISHAGE & $35.6 \pm 19.4(12.7-85.1)$ & $0.281 \pm 0.153(0.100-0.795)$ \\
ProCount $^{\text {TM }}$ & $36.6 \pm 23.2(14.1-110.4)$ & $0.285 \pm 0.174(0.091-0.806)$ \\
\hline
\end{tabular}

Data are reported as means $\pm S D$ with range in parentheses for 26 units of cord blood. ISHAGE = International Society of Hematotherapy and Graft Engineering.

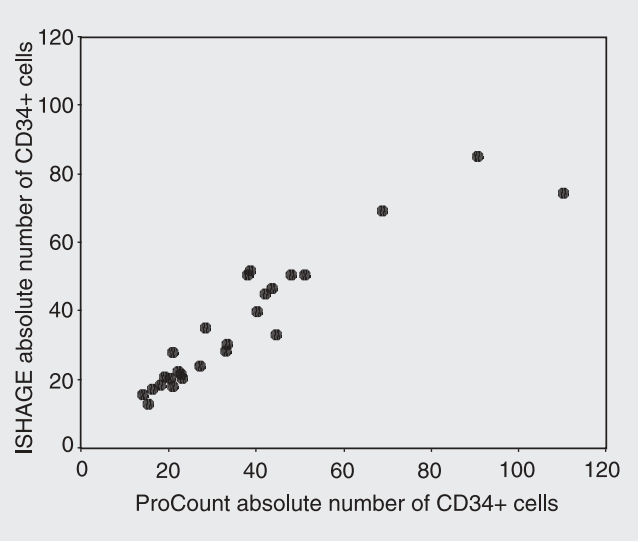

Figure 1. Comparison of two methods for quantitative measurement of the absolute number of CD34+ cells/ $\mu \mathrm{L}$ in cord blood. Each point represents the results of one cord blood sample, evaluated with the International Society of Hematotherapy and Graft Engineering (ISHAGE) and ProCount ${ }^{T M}$ protocols. The Statistical Package for the Social Sciences (SPSS, version 8) was used and the results were compared by the Student t-test. The correlation was statistically significant $(P<0.05)$. 
neous analysis of CD34 and 7AAD labeling with the ISHAGE protocol showed that among total CD $34+$ cells $32.8 \pm 14.0 \%$ (14.7$71.0 \%$ ) were $7 \mathrm{AAD}$-positive and that, whereas $22.1 \pm 13.8 \%(5.6-67.0 \%)$ were CD34+ bright cells, the remaining $77.0 \pm$ $13.8 \%$ (32.9-93.6\%) presented regular fluorescence.

Individual analysis of CD34+ bright and regular cells showed that 7AAD-positive cells were $98.0 \pm 2.8 \%(89.3-100.0 \%)$ of the CD34+ bright cells and only $13.9 \pm 5.3 \%$ (6.5-29.1\%) of the CD34+ regular cells. 7AAD-positive cells were further analyzed for dim and regular fluorescence (Table 2). These results indicate that only about 1.8\% of the bright CD34+ cells were alive, whereas a small part (19.0\%) were undergoing apoptosis (7AAD dim) and most of them (79.2\%) were dead cells (7AAD regular).

\section{Discussion}

The total quantity of nucleated cells (TNC) in a cord blood unit is a determining factor in the "taking" of the graft, the survival of the patient and the success of the transplant. Only those units of cord blood in which the level of TNC is greater than or equal to $3.7 \times 10^{7}$ cells per $\mathrm{kg}$ of patient weight are recommended for transplant (18). According to Campagnoli et al. (19), the absolute number of CD45+ cells, which is a pan-leukocyte marker, in the cord blood is around $11.9 \pm 1.3 \times 10^{6} / \mathrm{mL}$. As there is a correlation between the TNC and the num-

Table 2. Qualitative analysis of bright CD34+ cells or CD34+ cells with regular fluorescence in relation to labeling with 7AAD.

\begin{tabular}{lrc}
\hline & \multicolumn{1}{c}{ 7AAD $+\operatorname{dim}$} & 7AAD + regular \\
\hline CD34+ bright & $19.0 \pm 8.4 \%(4.2-35.5 \%)$ & $79.2 \pm 10.0 \%(57.6-95.8 \%)$ \\
CD34+ regular & $4.7 \pm 2.9 \%(0.7-13.9 \%)$ & $9.2 \pm 4.6 \%(3.8-20.9 \%)$
\end{tabular}

Data are reported as means (\%) \pm SD with range in parentheses for 26 units of cord blood. 7AAD $=7$-amino actinomycin $D$. ber of CD34+ cells (20), umbilical cord blood banks throughout the world are increasingly counting only CD34+ cells, and using these numbers as a criterion for the selection of the umbilical cord unit to be used in transplants (21).

However, there is still a great deal of debate in the literature about the concentration of CD34+ cells in the human placenta and umbilical cord blood. Values of $0.4 \pm$ $0.03 \%$ of CD34+ cells have been reported among total CD $45+$ cells (19), $0.36 \pm 0.33 \%$ (22) or $1.3 \%$ (23) among mononuclear cells, and values between 0.01 and $1.71 \%$ among cord blood cells (24).

A great variation in the number of these cells in the cord blood has been reported in the literature (20,22,24-28). Hao et al. (22) observed a variation of 0.02 to $1.43 \%$ in the number of CD34+ cells in the total mononuclear cell population. There are a number of factors that may explain this high variation range, such as the observation that the number of CD34+ cells in the cord blood is heterogeneous by nature (20) or that the percentage of CD34+ cells in relation to the CD45+ cells or mononuclear cells in the cord blood is inversely proportional to the gestational age $(1,2,20,23,29-31)$.

The frequency of these cells is significantly higher in infants born prematurely than in infants born at full term $(2,23,29-32)$, diminishing rapidly in the peripheral blood of the newborn following birth (33). There also appears to be a strong and significant inverse correlation in the fetal liver between CD34+ cells (together with the total leukocytes) and gestational age (34).

Nevertheless, although gestational age is an important factor, the variation in the number of CD34+ cells in the placental and umbilical cord blood appears to be the result of natural heterogeneity (20), as a large rate of variation in the number of CD34+ cells was found in the cord blood of full-term newborn infants. Li et al. (33) found variations of around 10-fold in a study of cord 
blood from full-term newborn infants, and Brocklebank and Sparrow (35), studying fullterm umbilical cord samples, found a range of 22 to $600 \mathrm{CD} 34+$ cells $/ \mu \mathrm{L}$ in human umbilical cord blood.

The aims of the present study were to compare the two most frequently employed methods for quantifying stem cells in HUCB and analyze the bright CD34+ cells which have been suggested to represent cells in apoptosis, and which therefore do not contribute to engraftment. No statistically significant difference was found between the absolute number of CD34+ cells and the relative number of CD34+ cells among the CD45+ cells by the ISHAGE protocol, with exclusion of the 7AAD-positive cells, and the ProCount ${ }^{\mathrm{TM}}$ protocol with exclusion of bright CD34+ cells. Hence, we may conclude that both protocols are appropriate for the quantitative analysis of CD34+ cells in HUCB.

According to several investigators (1517), 7AAD identifies dead cells and weakly label apoptotic cells. Our results indicate that only about $1.8 \%$ of bright CD34+ cells are alive, while a small number (19.0\%) are cells in apoptosis (7AAD weakly fluorescent). The majority of them $(79.2 \%)$ were shown to be dead (with regular 7AAD fluorescence), and should not thus be considered when total CD34+ cells are counted for transplant. Similar results were reported by Lögdberg et al. (15), who showed that the bright CD34+ cells are in apoptosis. Greco et al. (16) have also reported a high frequency of CD34+ bright cells in HUCB using the ProCount ${ }^{\mathrm{TM}}$ protocol.

Many studies in the literature show that 7AAD is important for the quantification of CD34+ cells in the ISHAGE protocol. Keeney et al. (36) showed that the use of 7AAD decreased the presence of CD34+ cells per microliter of blood by $50 \%$, suggesting that these were non-viable cells. This is particularly important after thawing of samples from umbilical cord blood banks or culture of umbilical cord blood samples (17, 26,37,38). Thus, it has been suggested that 7AAD should be routinely used for quantification of CD34+ cells in the ISHAGE protocol (36).

The results presented here will be useful to assist in the accurate counting of CD34+ cells as well as in choosing the best cord blood unit for transplantation, i.e., the unit with the greatest number of potentially viable stem cells for the reconstitution of bone marrow. This increases the likelihood of success of the transplant and, therefore, the survival of the patient.

\section{References}

1. Gasparoni A, Ciardelli L, Avanzini MA, Bonfichi M, di Mario M, Piazzi $G$, et al. Immunophenotypic changes of fetal cord blood hematopoietic progenitor cells during gestation. Pediatr Res 2000; 47: 825829.

2. J in $\mathrm{CH}$, Takada $\mathrm{H}$, Nomura A, Takahata $\mathrm{Y}$, Nakayama $\mathrm{H}$, Kajiwara $M$, et al. Immunophenotypic and functional characterization of CD33(+)CD34(+) cells in human cord blood of preterm neonates. Exp Hematol 2000; 28: 1174-1180.

3. Verfaillie CM. Anatomy and physiology of hematopoiesis. In: Hoffman R, Benz EJ, Shattil SJ , Furie B, Cohen HJ , Silberstein LE, et al. (E ditors), Hematology - basic principles and practice. 3rd edn. New York: Churchill Livingstone; 2000.

4. Williams DA. Stem cell model of hematopoiesis. In: Hoffman R, Benz EJ, Shattil SJ, Furie B, Cohen HJ, Silberstein LE, et al. (Editors), Hematology - basic principles and practice. 3rd edn. New
York: Churchill Livingstone; 2000.

5. Quesenberry PJ, Colvin GA. Hematopoietic stem cells, progenitor cells, and cytokines. In: Williams J W, Beutler E, Coller BS, Lichtman MA, Kipps TJ, Seligsohn U (Editors), Hematology. 6th edn. New York: McGraw-Hill; 2001.

6. Chivu M, Diaconu CC, Bleotu C, Alexiu I, Brasoveanu L, Cernescu C. The comparison of different protocols for expansion of umbilicalcord blood hematopoietic stem cells. J Cell Mol Med 2004; 8: 223231

7. Hirata $\mathrm{Y}$, Sata M, Motomura N, Takanashi M, Suematsu $\mathrm{Y}$, Ono M, et al. Human umbilical cord blood cells improve cardiac function after myocardial infarction. Biochem Biophys Res Commun 2005; 327: 609-614.

8. McNiece I, Kubegov D, Kerzic P, Shpall EJ, Gross S. Increased expansion and differentiation of cord blood products using a two- 
step expansion culture. Exp Hematol 2000; 28: 1181-1186.

9. Wada RK, Bradford A, Moogk M, Y im R, Strong DM, Drachman J, et al. Cord blood units collected at a remote site: a collaborative endeavor to collect umbilical cord blood through the Hawaii Cord Blood Bank and store the units at the Puget Sound Blood Center. Transfusion 2004; 44: 111-118.

10. McNiece I, Briddell R. Ex vivo expansion of hematopoietic progenitor cells and mature cells. Exp Hematol 2001; 29: 3-11.

11. Perotti CG, Del Fante C, Viarengo G, Papa P, Rocchi L, Bergamaschi $P$, et al. A new automated cell washer device for thawed cord blood units. Transfusion 2004; 44: 900-906.

12. Cohen $Y$, Nagler A. Umbilical cord blood transplantation - how, when and for whom? Blood Rev 2004; 18: 167-179.

13. Laughlin $M J$, Eapen $M$, Rubinstein $P$, Wagner J E, Zhang MJ, Champlin RE, et al. Outcomes after transplantation of cord blood or bone marrow from unrelated donors in adults with leukemia. $\mathrm{N} \mathrm{Engl}$ J Med 2004; 351: 2265-2275.

14. Sutherland DR, Anderson L, Keeney M, Nayar R, Chin-Yee I. The ISHAGE guidelines for CD34+ cell determination by flow cytometry. International Society of Hematotherapy and Graft Engineering. J Hematother 1996; 5: 213-226.

15. Lögdberg L, Hendrikx J, Alespeiti G, Rafii S, Rubinstein P, Visser JWM. On the nature of CD34+ bright staining cells in human umbilical cord blood. Implications for estimating stem cells by CD34 counts. Blood 2000; 96 (Suppl 1): 381 (Abstract).

16. Greco NJ, Lee WR, Kurt J, Seetharaman S, Moroff G. Characterization of multiple CD34+ cell populations in cord blood. J Hematother Stem Cell Res 2003; 12: 199-213.

17. Philpott NJ, Turner AJ, Scopes J, Westby M, Marsh J C, GordonSmith EC, et al. The use of 7-amino actinomycin $D$ in identifying apoptosis: simplicity of use and broad spectrum of application compared with other techniques. Blood 1996; 87: 2244-2251.

18. Gluckman E, Rocha V, Boyer-Chammard A, Locatelli F, Arcese W, Pasquini $R$, et al. Outcome of cord-blood transplantation from related and unrelated donors. Eurocord Transplant Group and the European Blood and Marrow Transplantation Group. N Engl J Med 1997; 337: 373-381.

19. Campagnoli C, Fisk N, Overton T, Bennett P, Watts T, Roberts I. Circulating hematopoietic progenitor cells in first trimester fetal blood. Blood 2000; 95: 1967-1972.

20. Yap C, Loh MT, Heng KK, Tan P, Yu SL, Chan SH, et al. Variability in CD34+ cell counts in umbilical cord blood: implications for cord blood transplants. Gynecol Obstet Invest 2000; 50: 258-259.

21. Aroviita P, Teramo K, Hiilesmaa V, Westman P, Kekomaki R. Birthweight of full-term infants is associated with cord blood CD34+ cell concentration. Acta Paediatr 2004; 93: 1323-1329.

22. Hao QL, Shah AJ, Thiemann FT, Smogorzewska EM, Crooks GM. A functional comparison of CD34t. Blood 1995; 86: 3745-3753.

23. Shields LE, Andrews RG. Gestational age changes in circulating CD34+ hematopoietic stem/progenitor cells in fetal cord blood. Am J Obstet Gynecol 1998; 178: 931-937.
24. D'Arena G, Musto P, Cascavilla N, Di Giorgio G, Zendoli F, Carotenuto M. Human umbilical cord blood: immunophenotypic heterogeneity of $\mathrm{CD} 34+$ hematopoietic progenitor cells. Haematologica 1996; 81: 404-409.

25. Pranke $P$, Failace RR, Allebrandt WF, Steibel G, Schmidt F, Nardi NB. Hematologic and immunophenotypic characterization of human umbilical cord blood. Acta Haematol 2001; 105: 71-76.

26. Pranke P, Hendrikx J, Debnath G, Alespeiti G, Rubinstein P, Nardi $\mathrm{N}$, et al. Immunophenotype of hematopoietic stem cells from placental/umbilical cord blood after culture. Braz J Med Biol Res 2005; 38: 1775-1789.

27. Chivu M, Diaconu CC, Brasoveanu L, Alexiu I, Bleotu C, Banceanu $G$, et al. Ex vivo differentiation of umbilical cord blood progenitor cells in the presence of placental conditioned medium. J Cell Mol Med 2002; 6: 609-620.

28. Lakshmipathy U, Verfaillie C. Stem cell plasticity. Blood Rev 2005; 19: 29-38.

29. Meister B, Totsch M, Mayr A, Widschwendter M, Huter O, Sperl W. Identification of CD34+ cord blood cells and their subpopulations in preterm and term neonates using three-color flow cytometry. Biol Neonate 1994; 66: 272-279.

30. Thilaganathan B, Nicolaides KH, Morgan G. Subpopulations of CD34-positive haemopoietic progenitors in fetal blood. $\mathrm{Br}$ J Haematol 1994; 87: 634-636.

31. Opie TM, Shields LE, Andrews RG. Cell-surface antigen expression in early and term gestation fetal hematopoietic progenitor cells. Stem Cells 1998; 16: 343-348.

32. Surbek DV, Steinmann C, Burk M, Hahn S, Tichelli A, Holzgreve W Developmental changes in adhesion molecule expressions in umbilical cord blood CD34 hematopoietic progenitor and stem cells. Am J Obstet Gynecol 2000; 183: 1152-1157.

33. Li K, Yau FW, Fok TF, So KW, Li CK, Yuen PM. Haematopoietic stem and progenitor cells in human term and preterm neonatal blood. Vox Sang 2001; 80: 162-169.

34. Kilpatrick DC, Atkinson AP, Palmer J B, Murphy WG, Turner ML. Developmental variation in stem-cell markers from human fetal liver and umbilical cord blood leukocytes. Transfus Med 1998; 8: 103109.

35. Brocklebank AM, Sparrow RL. Enumeration of CD34+ cells in cord blood: a variation on a single-platform flow cytometric method based on the ISHAGE gating strategy. Cytometry 2001; 46: 254-261.

36. Keeney M, Gratama J W, Sutherland DR. Critical role of flow cytometry in evaluating peripheral blood hematopoietic stem cell grafts. Cytometry A 2004; 58: 72-75.

37. Bayer-Zwirello LA, Hoffman DE, Adams LA, Wilder PT, Reece MT. The effect of processing and cryopreservation on nucleated umbilical cord blood cells. J Perinat Med 2004; 32: 430-433.

38. Van Haute I, Lootens N, De Smet S, De Buck C, Verdegem L, Vanheusden $\mathrm{K}$, et al. Viable CD34+ stem cell content of a cord blood graft: which measurement performed before transplantation is most representative? Transfusion 2004; 44: 547-554. 